\title{
Pemanfaatan Tumpi Jagung Fermentasi pada Penggemukan Domba Jantan Ekor Gemuk
}

\section{The utilization of tumpi corn fermentation on fattening the male sheep}

\author{
Suci Wulandari ${ }^{1}$, Hariadi Subagja ${ }^{2}$, Siti Mutmainnah ${ }^{3}$ \\ Jurusan Peternakan, Politeknik Negeri Jember, Jl. Mastrip PO BOX 164, Jember \\ ${ }^{1}$ suci_ndariwulandyahoo.com \\ ${ }^{2}$ hariadisubagja@gmail.com \\ ${ }^{3}$ mutmainnah.atnk@gmail.com
}

\begin{abstract}
This study aims to examine the use of fermented corn tumpi on the fat tail sheep fattening and sheep production performance which includes the consumption of feed dry matter (DM), daily weight gain, and feed conversion. The study consisted of three treatments, namely, control diet without tumpi corn fermentation (P0), feed containing 30\% tumpi fermentation (P1), and feed containing 60\% tumpi corn fermentation(P2). Replicates at each treatment consists of three sheep. The method used in this study is completely randomized design (CRD) using analysis of variance (ANOVA) and significantly different results in a further test using the least significant difference test (LSD). The results showed that the use of fermented corn tumpi are not significantly different (P> $0.05)$ on dry matter intake. But the use of fermented corn tumpi significantly different $(P<0.05)$ on daily weight gain and feed conversion. Average daily weight gain was the highest in P1 of $140.47 \mathrm{grams} / \mathrm{head} / \mathrm{day}$.
\end{abstract}

Keywords : Sheep, fattening, tumpi corn fermentation

\section{PENDAhuluan}

Domba merupakan ternak ruminansia kecil yang banyak dipelihara dan dikenal oleh masyarakat, terutama masyarakat pedesaan. Populasi domba pada tahun 2012 yaitu 13.42 juta ekor mengalami peninngkatan $13.82 \%$ dari tahun 2011 sebesar 11.79 juta ekor, populasi domba mengalami peningkatan yang di bilang lambat setiap tahunnya (Ditjennak, 2013). Hal yang menyebabkan lambatnya peningkatan populasi domba yaitu pemeliharaan, pakan, dll. Sistem pemeliharaan domba kebanyakan secara tradisionalyaitu domba banyak di pelihara oleh masyarakat pedesaan sebagai usaha sambilan.

Domba yang banyak di pelihara masyarakat adalah domba lokal salah satunya, yaitu domba ekor gemuk(DEG). Domba ekor gemuk (DEG) pada umumnya tersebar di Jawa Timur dengan daya adaptasi yang sangat baik terhadap berbagai lingkungan, terutama di daerah beriklim kering (Purbowati, 2009).

Akhir - akhir ini penggemukan domba mulai diminati oleh masyarakat, faktor yang menentukan penggemukan domba terletak pada kualitas dan kuantitas pakan. Pakan adalah salah satu kebutuhan pokok domba yang harus terpenuhi agar domba dapat tumbuh dan bertahan hidup. Pakan utama domba adalah hijauan, tetapi akhir-akhir ini ketersediaan hijauan mulai terbatas. Keterbatasan hijauan disebabkan karena keterbatasan lahan pengembalaan dan penyediaan hijauan pakan ternak yang mulai beralih fungsi dari lahan produktif menjadi lahan pemukiman dan kawasan industri.Oleh karena itu, perlu pakan alternatif sebagai pengganti hijauanyaitu dengan memanfaatkan sumberdaya lokal yang berupa limbah pertanian.

Pemanfataan limbah pertanian merupakan upaya untuk mengatasi masalah pakan ternak dan dapat menjadi pakan pengganti hijauan. Selain itu ketersediaan limbah pertanian cukup melimpah dan harganya relatif murah. Limbah pertanian memiliki kekurangan, yakni memiliki kandungana nutrisi yang rendah seperti kandungan $\mathrm{N}$ yang rendah dan kandungan selulosa yang tinggi. Akan tetapi terdapat beberapa limbah pertanian yang memiliki potensi yang cukup besar besar yaitu salah satunya tumpi jagung (Wahyono dan Hardiyanto, 2004).

Tumpi jagung adalah limbah dari hasil perontokan jagung pipilan yang ketersediaannya cukup kontinyu, tidak bersaing dengan manusia, dan harganya relatif murah. Pada musim panen raya jagung tumpi jagung kadang di buang karena 
Suci Wulandari, Hariadi Subagja, Siti Mutmainnah.Pemanfaatan Tumpi Jagung Fermentasi pada

Penggemukan Domba Jantan Ekor Gemuk

keberadaannya dianggap mengganggu. Tumpi jagung sendiri belum di manfaatkan secara optimal untuk pakan ternak ketersediaannya cukup terjangkau.Kandungan nutrien yang terdapat dalam tumpi jagung adalah bahan kering (BK) 88,28\%, protei kasar (PK) 8,04\%, serat kasar (SK) 11,70\%, dan total digestible nutrien (TDN) $51,16 \%$ (Mariyono, dkk. 2005).

Tumpi jagung bersifat amba (bulky), sehingga membutuhkan penerapan bioteknolgi untuk membuat tumpi jagung lebih di senangi oleh ternak. Apabila tumpi jagung diberikan langsung pada ternak atau tumpi jagung di campur pada konsentrat kurang disenangi ternak karena teksturnya kasar, sedang jika diberikan dalam keadaan basah tumpi jagung akan mengapung (Mariyono, dkk. 2005). Maka tumpi jagung harus di proses sebelum digunakan sebagai pakan ternak, proses pembuatan pakan menggunakan tumpi jagung dapat melalui fermentasi.

Fermentasi adalah salah satu bioteknologi yang dapat di terapkan untuk mengolah tumpi jagung menjadi pakan yang disenangi oleh ternak, karena pada saat proses fermentasi terdapat perombakan struktur yang komplek menjadi sederhana sehingga daya cerna lebih efisein, karena dengan fermentasi serat kasar yang tinggi dapat didegredasi menggunakan mikroorganisme. Menurut Novianty (2014), proses fermentasi dilakukan untuk meningkatkan nilai gizi bahan kualitas rendah, pengawetan bahan pakan dan merupakan suatu cara untuk menghilangkan zat anti nutrisi atau racun yang terkandung dalam suatu bahan pakan. Selain itu, proses fermentasi dapat memperpanjang masa penyimpanan, mengendalikan pertumbuhan mikrobia, mempertahankan gizi yang di kehendaki, dan menciptakan kondisi yang kurang memadai untuk mikrobia kontaminan.

Proses fermentasi pada tumpi jagung dapat menggunakan EM-4 (Effective Microorganisme). EM-4 merupakan suatu kultur campuran berbagai mikroorganisme yang bermanfaat terutama Lactobacillus, bakteri fotosintetik, actynomycetes, ragi dan jamur fermentasi. EM-4 bermanfaat menyehatkan ternak, mengurangi stres pada ternak, meningkatkan nafsu makan, dll.

Berdasarkan uraian latar belakang di atas, peneliti ingin mengetahui manfaat tumpi jagung fermentasi pada penggemukan domba jantan ekor gemuk.

\section{METODE PENELITIAN}

Penelitian dilaksanakan di kandang domba Bapak Munawar, Jln. Raya Banyuwangi RT/RW: 11/04, Dusun Banyutingal, Desa Lamungan, Kec. Arjasa - Situbondo. Waktu pelaksanaan penelitian selama 10 minggu yaitu pada bulan Juni s/d September 2016.

Bahan yang digunakan dalam penelitian ini yaitu, 9 domba jantan ekor gemuk yang berumur \pm 10 - 12 bulan dengan bobot badan $17 \mathrm{~kg}$ sampai dengan $24 \mathrm{~kg}$ sebanyak 9 ekor, EM-4 (Effective Microorganisme), tetes, sabun atau detergent,pakan berupa hijauan, tumpi jagung fermentasi, dan konsentrat.

Metode yang digunakan dalam penelitian ini adalah metode eksperimen yang disusun dalam rancangan acak lengkap (RAL), dengan 3 perlakuan dan 3 ulangan sehingga membutuhkan domba sebnyak 9 ekor ternak domba. Perlakuan yang digunakan adalah : (kontrol)

$\mathrm{P0}=$ pakan tanpa fermentasi tumpi jagung

P1 = pakan dengan fermentasi tumpi jagung sebanyak $30 \%$

$\mathrm{P} 2$ = pakan dengan fermentasi tumpi jagung sebanyak $60 \%$

Pakan dalam peneliian ini diformulasi sesuai dengan kebutuhan nutrisi domba. Formulasi pakan meliputi P0 (Tanpa Tumpi Jagung Fermentasi), P1 (Menggunakan Tumpi Jagung Fermentasi 30\%), P2 (Mengggunakan Tumpi Jagung Fermentasi 60\%). Bahan pakan pada P0 terdiri dari, rumput lapang $85 \%$, dedak halus $11 \%$, bungkil kedelai $3 \%$, dan Premix 1\%. Bahan pakan untuk P1 meliputi rumput lapang 50\%, tumpi jagung fermentasi $30 \%$, dedak halus $10 \%$, bungkil kedelai $3 \%$, pollard $6 \%$, dan premix $1 \%$. Sedangkan, bahan pakan untuk P2 meliputi rumput lapang $15 \%$, tumpi jagung fermentasi $60 \%$, dedak halus $10 \%$, bungkil kedelai $3 \%$, pollard $11 \%$ dan premix $1 \%$. Tumpi Jagung di fermentasi secara anaerob selama 7 hari.

Persiapan kandang dan peralatan. Kandang di sekat terlebih dahulu menjadi kandang individu, kemudian di bersihkan dan di semprot disenfektan. pembersihan kandang dilakukan 7 hari sebelum domba datang. Peraltan kandang juga di bersihkan dan di rendam di air yang tercampur disenfektan. Awal pemeliharaan domba di mandikan, kemudian pemberian B kompleks dan obat cacing.

Adaptasi pakan dilakukan selama 2 minggu. Penimbangan domba dilakukan pada awal pemeliharaan, selama pemeliharaan 1 minggu sekali, dan diakhir pemeliharaan. Pemberian pakan dilakukan 2 kali sehari yaitu pada jam 08.00 dan 16.00 WIB. Kandang domba di bersihkan setiap hari untuk menjaga kebersihan area kandang.

\section{Analisis Statistik}

Data yang diperoleh dari perhitungan yang menggunakan RAL (Rancangan Acak Lengkap) kemudian di analisa menggunakan analisis of varian (anova). 
TABEL 1 RAGAM ANOVA

\begin{tabular}{llcccc}
\hline SK & Db & JK & KT & F hitung & F table \\
\hline Perlakuan & $\mathrm{t}-1$ & $\frac{\epsilon r-F K}{t}$ & $\frac{J K P}{d b P e r l a k u a n}$ & KTP/KTG & \\
Galat & $(\mathrm{t})(\mathrm{r}-1)$ & $\mathrm{JKT}-\mathrm{JKP}$ & $\frac{J K G}{\text { dbGalat }}$ & & \\
\hline Total & $(\mathrm{t} . \mathrm{r}-1)$ & $\mathrm{JKT}$ & & & \\
\hline
\end{tabular}

apabila terdapat perbedaan maka dilanjutkan dengan uji beda nyata terkecil (BNT) 5\% dan 1\%.

\section{Parameter Pengamatan}

Parameter pengamatan dalam penelitian ini adalah pertambahan bobot badan perminggu, pertambahan bobot akhir, konsumsi pakan (bahan kering dan segar), dan konversi pakan ternak domba ekor gemuk jantan.

Konsumsi Bahan Kering

Konsumsi pakan (rata - rata konsumsi pakan) dihitung setiap hari selama pemeliharaan berlangsung. Perhitungan konsumsi pakan diperoleh dari selisih pakan yang diberikan dengan sisa pakan dan dinyatakan dalam gram per ekor per hari.

Konsumsi BK $=\left\{\left(\sum\right.\right.$ Pemberian $\mathrm{x}$ BK Pakan Pemberian \% $)$ - ( $($ Sisa Pakan Hijauan x BK Hijauan Sisa\%)- ( $\sum$ Sisa Pakan Konsentrat $\mathrm{x}$ BK Konsentrat Sisa\%)\}

Konsumsi Pakan Segar $=\sum$ Konsumsi Bahan Kering $\mathrm{x}$ $\frac{100}{\text { BK Pakan }}$

Pertambahan Bobot Badan (gram)

Pertambahan Bobot badan dapat diperoleh dari pertambahan bobot badan diperoleh dari hasil pengurangan bobot badan akhir (yang telah ditimbang satu minggu sekali) dengan penimbangan bobot badan minggu sebelumnya. Penimbanagan silakukan seminggu sekali.

$\mathrm{PBB}=\mathrm{BB}$ Akhir (gram/ekor) $-\mathrm{BB}$ Awal (gram/ekor)

Petambahan Bobot Badan Harian (PBBH) diperoleh dari perhitungan dengan cara membagi selisih bobot badan (bobot akhir - bobot awal) dengan lama hari penimbangan dan dinyatakan dalam gram per ekor per hari. Dilakukan seminggu sekali.

Bobot akhir - Bobot awal (gram/ekor)

$\mathrm{PBBH}$

$$
\text { Lama Pemeliharaan (hari) }
$$

Konversi Pakan

Feed Convertion Ratio atau rasio konversi pakan merupakan satuan untuk menghitung efisiensi pakan pada budidaya pembesaran dan penggemukan. konversi dihitung dari konsumsi pakan dibagi TABEL 2 RATA - RATA KONSUMSI BK HARIAN (GRAM/EKOR/HARI)

\begin{tabular}{llll}
\hline \multirow{2}{*}{ Ulangan } & \multicolumn{3}{c}{ Perlakuan } \\
\cline { 2 - 4 } & Kontrol & $30 \%$ & $60 \%$ \\
\hline 1 & 1424,71 & 1579,66 & 1526,07 \\
2 & 1340,27 & 1421,53 & 1414,62 \\
\hline
\end{tabular}

dengan pertambahan bobot badan. Perhitungan konversi pakan dilakukan setiap seminggu sekali selama masa pemulihan. Perhitungan ini dimaksudkan untuk mengetahui tingkat efisiensi pakan yang telah dicapai. Perhitungan konsumsi pakan ini diperoleh dari pembagian jumlah rata-rata konsumsi pakan kumulatif per ekor dengan rata-rata pertambahan bobot badan masing-masing ternak.

$$
\text { Konversi Pakar } \frac{\text { Konsumsi BK (gram/hari) }}{\text { PBBH (gram/hari) }}
$$

\section{III.HASIL DAN PEMBAHASAN}

\section{Formulasi Pakan pada Domba Jantan Ekor Gemuk}

Formulasi pakan dalam penelitian ini sesuai pada metode penelitian. Formulasi pakan pada penelitian di hitung sesuai proporsi yang di butuhkan domba dalam memenuhi kebutuhan nutrisinya. Kandungan nutrisi pada formulasi pakan P0 yaitu PK $12,97 \%$ dan TDN 62,28\%. Kandungan nutrisi pada formulasi P1 yaitu PK 12,90\% dan TDN 62,38\%. Sedangkan, kandungan nutrisi P2 yaitu PK 12,81\% dan TDN 62,28\%. Bahan kering (BK) pemberian yang digunakan pada penelitian ini yaitu 5\% dari berat badan domba. Menurut Ranjhan dalam kebutuhan nutrisi domba dengan berat badan $25 \mathrm{~kg}$ dan pertambahan bobot badan sebesar 100 gram/hari membutuhkan pakan dengan kandungan PK sebesar $12,7 \%$, TDN sebesar 60\%, dan BK 3-5\% dari bobot badan. Jadi, formulasi pakan yang digunakan dalam penelitian ini mampu memenuhi kebutuhan nutrisi domba.

\section{Pengaruh Perlakuan terhadap Konsumsi Bahan Kering}

Rata-rata konsumsi bahan kering dan komsumsi segar domba jantan ekor gemuk dengan pemberian tumpi jagung fermentasi ditunjukkan pada tabel 2 . Wulandari, dkk. (2014), menyatakan bahwa 
Suci Wulandari, Hariadi Subagja, Siti Mutmainnah.Pemanfaatan Tumpi Jagung Fermentasi pada Penggemukan Domba Jantan Ekor Gemuk

\begin{tabular}{cccc}
\hline 3 & 1066,29 & 1175,72 & 1408,73 \\
\hline Rata-rata $^{\text {ns }}$ & 1277,09 & 1392,30 & 1449,81 \\
\hline \multirow{2}{*}{ Ulangan } & TABEL 3 RATA- RATA KonsuMSI PAKAN SEGAR (GRAM/EKOR/HARI) & \\
\cline { 2 - 4 } 1 & Perlakuan & & $60 \%$ \\
\hline 2 & Kontrol & $30 \%$ & 2149,39 \\
3 & 4317,29 & 3037,81 & 1992,42 \\
\hline Rata-rata & 4061,43 & 2733,71 & 1948,13 \\
\hline ns & 3231,17 & 2261,00 & 2029,98 \\
\hline
\end{tabular}

Keterangan: $\quad$ Perlakuan Kontrol: Tanpa Tumpi Jagung Fermentasi (P0)

Perlakuan 30\%: Tumpi Jagung Fermentasi sebanyak 30\% (P1)

Perlakuan 60\% : Tumpi Jagung Fermentasi sebanyak 60\%(P2)

ns : Non Significant (tidak berbeda nyata)

Rata - rata konsumsi bahan kering pakan pada memberikan respon yang sama terhadap konsumsi perlakuan PO, P1, P2, secara berturut - turut adalah 1277,09; 1392,30; 1449,81 gram/ekor/hari. Konsumsi segar domba tersebut setara dengan komsumsi BK yang di berikan pada perlakuan. Tabel data konsumsi BK harian diketahui bahwa terdapat perbedaan jumlah konsumsi pakan pada setiap perlakuan dalam penelitian. Menurut Purbowati (2009), konsumsi BK dipengaruhi oleh bangsa, jenis ternak, umur, palatabilitas pakan dan kondisi ternak.

Hasil analisis sidik ragam terhadap konsumsi bahan kering menunjukkan bahwa konsumsi bahan kering domba tidak berbeda nyata $(\mathrm{P}>0,05)$ antar perlakuan, artinya pemanfaatan tumpi jagung fermentasi pada penggemukan domba ekor gemuk bahan kering. Menurut Parakkasi (1999) dalam Wulandari (2014), menyatakan bahwa faktor yang mempengaruhi konsumsi pakan yaitu meliputi ternak yang bersangkutan, pakan yang diberikan, dan kondisi lingkungan termpat ternak tersebut dipelihara.

Konsumsi bahan kering relatif stabil, bahkan meningkat sesuai kebutuhan domba setiap minggunya.Kebutuhan BK meningkat setiap minggunya, hal ini disebabkan karena berat badan yang semakin meningkat. Menurut Zain (2009), konsumsi pakan akan meningkat sejalan dengan semakin bertambah besarnya ternak.

\section{Pengaruh Perlakuan Terhadap Bobot Badan}

Rata-rata PBBH domba ekor gemuk domba jantan dengan pemberian tumpi jagung fermentasi ditunjukan pada Tabel 4 dan lampiran 6.

TABEL 4 PBB DOMBA HARIAN (GRAM/EKOR/HARI)

\begin{tabular}{llll}
\hline \multirow{2}{*}{ Ulangan } & Perlakuan & \\
\cline { 2 - 4 } & Kontrol & $30 \%$ & $60 \%$ \\
\hline 1 & 142,86 & 157,14 & 100 \\
2 & 121,43 & 135,71 & 114,29 \\
3 & 135,71 & 128,57 & 114,29 \\
\hline Rata-rata & $133,33^{\text {a }}$ & $140,47^{\text {a }}$ & $109,53^{\text {b }}$ \\
\hline
\end{tabular}

Keterangan: ${ }^{a}, b=$ Superskrip yang berbeda menunjukkan perbedaan yang nyata $(\mathrm{P}<0,05)$

Pada Tabel 4 diketahui bahwa ada perbedaan tingkat pertambahan bobot badan antar perlakuan dalam penelitian. Rata - rata pertambahan bobot badan P0, P1, P2 berturut - turut adalah 133,33; 140,47; 109,53 gram/ekor/hari.

Hasil analisis sidik ragam terhadap pertambahan bobot badan menunjukkan bahwa pertambahan bobot badan domba berbeda nyata $(\mathrm{P}<0,05)$ antar perlakuan. Hasil uji lanjut dengan menggunakan BNT menunjukkan bahwa domba yang menggunukan tumpi jagung fermentasi $60 \%$ (P2) berbeda nyata $(\mathrm{P}<0,05)$ terhadap domba $\mathrm{P} 0$ (Tanpa Tumpi Jagung Fermentasi) dan P1 (Tumpi
Jagung Fermentasi 30\%) pada pertambahan bobot badan, namun domba P0 tidak berbeda nyata pada domba P1. Perbedaan PBBH antar perlakuan dikarenakan adanya perbedaan konsumsi BK pada setiap perlakuan. Menurut Parakkasi (1999) dalam Wulandari (2014), PBBH dipengaruhi oleh konsumsi pakan domba. Jadi, semakin tinggi konsumsi BK yang dikonsumsi domba maka semakin tinggi pertambahan bobot badan domba tersebut. Konsumsi BK pada perlakuan P2 tidak berbeda nyata $(\mathrm{P}>0,05)$ pada $\mathrm{P} 1$ dan $\mathrm{P} 2$ dimungkinkan pemberian tumpi jagung fermentasi $>30 \%$ sulit dicerna dan diserap oleh domba, karena tumpi 
jagung mengandung zat anti nutrisi berupa pektin. Pektin adalah serat kasar yang yang memiliki struktur mirip selulosa, hanya saja pektin memiliki gugus metil ester. Menurut Lubis (1992) dalam Ningrum (2010), bahwa kadar serat kasar yang terlalu tinggi dapat mengganggu pencernaan zat-zat lainnya sehingga daya cerna dari bahan pakan itu rendah.Selain itu, kesehatan domba pada perlakuan P2 yang mengalami sakit mencret juga mempengaruhi pertambahan bobot badan domba harian. Purbowati (2009), menyatakan bahwa laju pertumbuhan domba di tentukan oleh faktor potensi genetik, pakan, kesehatan, dan lingkungan.

Rata - rata pertambahan bobot badan domba harian tertinggi dicapai oleh ternak domba pada P1 (Tumpi jagung fermentasi 30\%) sebesar 140,47 g/ekor/hari, sedangkan pertambahan bobot badan domba terendah yaitu P2 sebesar 109,53 gram/ekor/hari. PBBH dipengaruhi oleh konsumsi pakan, semakin tinggi konsumsi BK maka semakin tinggi juga pertambahan bobot hidup domba (Parakkasi, 1995 dalam Rianto, dkk., 2006). Selain

\section{Pengaruh Perlakuan Terhadap Konversi}

Pakan

Rata-rata konversi pakan domba ekor gemuk domba jantan ekor gemuk dengan pemberian tumpi jagung fermentasi dicantumkan pada Table 5.

TABEl 5 KONVERSi PAKAN DOMBA

\begin{tabular}{llll}
\hline \multirow{2}{*}{ Ulangan } & Perlakuan & \\
\cline { 2 - 4 } & Kontrol & $30 \%$ & $60 \%$ \\
\hline 1 & 9,97 & 10,05 & 15,26 \\
2 & 11,04 & 10,47 & 12,38 \\
3 & 7,86 & 9,14 & 12,33 \\
\hline Rata-rata & $9,62^{\mathrm{a}}$ & $9,89^{\mathrm{a}}$ & $13.32^{\mathrm{b}}$ \\
\hline
\end{tabular}

Keterangan: ${ }^{a}, b=$ Superskrip yang berbeda menunjukkan perbedaan yang nyata $(\mathrm{P}<0,05)$

Rata - rata konversi pakan untuk masing masing perlakuan yaitu 9,62 (P0); 9,89 (P1); dan 13,32 (P2). Angka konversi pakan tersebut artinya untuk meningkatkan $1 \mathrm{~kg}$ berat badan domba membutuhkan 9,62 kg BK pakan untuk P0 (tanpa tumpi jagung fermentasi), 9,89 kg BK pakan untuk Pl (30\% tumpi jagung fermentasi), 13,32 kg BK pakan untuk P2 (60\% tumpi jagung fermentasi). Konversi pakan pada penelitian ini cukup baik. Hal ini karena, menurut Purbowati dkk. (2009), konversi pakan domba daerah tropis berkisar antara $7-15$, yang artinya untuk menghasilkan $1 \mathrm{~kg}$ berat badan domba membutuhkan 7 - $15 \mathrm{~kg}$ BK pakan.

Konversi pakan menunjukkan tingkat efisiensi penggunaan pakan. Angka konversi yang kecil menunjukkan penggunaan pakan yang efesien, dan sebaliknya angka konversi yang besar menunjukkan bahwa penggunaan pakan tidak efesien. Rata - rata konversi pakan pada penilitian di sajikan pada tabel 4.3.Hasil analisis sidik ragam menunjukkan bahwa pemanfaatan tumpi jagung itu, kecepatan pertumbuhan domba juga selalu berbeda - beda karena dipengaruhi oleh bangsa domba, umur, jenis kelamin, genetik dan lingkungan (Baihaqi, dkk., 2004).

Pertambahan bobot badan pada perlakuan P0, P1, dan P2 yaitu berkisar antara 109,53 - 140,47 gram/ekor/hari lebih tinggi dari hasil penelitian Wulandari (2014) yang mencapai 147,1 gram/ekor/hari. Hal ini karena penyajian pakan pada penelitian ini yaitu dengan memisahkan antara pemberian hijauan dan konsentrat. Penyajian pakan dengan terpisah akan memberikan kesempatan domba untuk memimilih bahan pakan yang akan dikonsumsi dalam pakannya, sehingga pakan yang dikonsumsi kurang efesien (Wulandari, dkk., 2014). Selain itu, kenaikanbobot badan terjadi apabila pakan yang dikonsumsi ternak melebihi kebutuhan hidup pokok, maka kelebihan nutrien akan diubah menjadi urat daging dan lemak, sehingga pertambahan bobot badan tampak jelas (Williamson and Payne, 1993 dalam Rianto, dkk., 2006).

fermentasi sampai taraf $60 \%$ berbeda nyata $(\mathrm{P}<0,05)$ terhadap konversi pakan. Hasil uji lanjut dengan menggunakan BNT menunjukkan bahwa penggunaan tumpi jagung fermentasi pada taraf $60 \%$ berbeda nyata $(\mathrm{P}<0.05)$ terhadap domba P0 (Tampa Tumpi Jagung Fermentasi) dan P1 (Tumpi Jagung Fermentasi 30\%) pada konversi pakan domba. Hal ini menunjukkan bahwa pemanfaatan tumpi jagung fermentasi pada taraf $60 \%$ kurang efesien dibandingkan P0 dan P1. Menurut Marhaeniyanto dan Hananik (2009), nilai konversi tergantung pada konsumsi bahan kering dan pertambahan bobot badan harian, akan tetapi konsumsi bahan kering yang rendah belum tentu menyebabkan konversi pakan yang tinggi sebaliknya konsumsi BK yang tinggi belum tentu menyebabkan konversi pakan yang tinggi, karena nilai konsumsi $\mathrm{BK}$ tergantung pada kualitas pakan dan PBBH domba.Hal ini juga diperkuat oleh Siregar (1994), yang menyatakan bahwa konversi pakan dipengaruhi oleh ketersediaan zat-zat gizi dalam ransum dan kesehatan ternak, 
Suci Wulandari, Hariadi Subagja, Siti Mutmainnah.Pemanfaatan Tumpi Jagung Fermentasi pada Penggemukan Domba Jantan Ekor Gemuk

semakin tinggi nilai konversi pakan berarti pakan yang digunakan untuk menaikkan bobot badan persatuan berat semakin banyak atau efisiensi pakan rendah.

\section{IV.KESIMPULAN DAN SARAN}

A. Kesimpulan

Berdasarkan hasil penelitian ini dapat disimpulkan bahwa pemanfaatan tumpi jagung fermentasi pada penggemukan domba ekor gemuk tidak perbeda nyata pada konsumsi bahan kering, namun berbeda nyata pada pertambahan bobot badan harian domba dan konversi pakan domba.Pemberian tumpi jagung fermentasi memiliki respon yang sama pada konsumsi bahan kering, dan memberikan respon yang berbeda pada pertambahan bobot badan. Pertambahan bobot badan tertinggi yaitu pada domba yang diberikan tumpi $30 \%$ yaitu sebesar 140,47 gram/ekor hari.

\section{B. Saran}

Pemanfaatan tumpi jagung untuk menghasilkan pertambahan bobot badan disarankan pada pemberian tumpi jagung pada P1 (30\%).

\section{UCAPAN TERIMA KASIH}

Penulis menyampaikan penghargaan dan ucapan terima kasih yang sebesar-besarnya kepada : dukungan pembiayaan melalui Program Beasiswa Bidikmisi, Direktur Politeknik Negeri Jember, Ketua Jurusan Peternakan, Ketua Program Studi Produksi Ternak, yang telah mensupport dan memberi kesempatan dalam pelaksanaan penelitian dan penulisan jurnal ini.

\section{DAFTAR PUSTAKA}

[1] Baihaqi, M., M. Duldjaman, dan Herman R. 2004. Penampilan Domba Lokal Yang Dikandangkan Dengan Pakan Kombinasi Tiga Macam Rumput (Bracharia humidicola, Bracharia decumbens, dan Rumput Alam). Lokakarya Nasional Domba dan Kambing: Strategi Peningkatan Produksi dan Mutu Bibit Domba dan Kambing. Hlm. 155 - 161. Fakultas Peternakan IPB. [2] Ditjennak. 2013. Statistik Peternakan dan Kesehatan Hewan 2013. Jakarta: Direktorat Jendral Peternakan dan Kesehatan Hewan Kementerian Pertanian RI.

[3] Marhaeniyanto, Eko, dan Hananik Prasetyo. 2009. Suplementasi pada Pakan Basal Tumpi Jagung dan Kulit Kopi Terhadap Kinerja Domba Jantan Muda. Dalam Buana Sains. Vol.9 No.2: 119-128.

[4] Mariyono, D. B. Wijono, dan Hartati. 2005. Teknologi Pakan Murah untuk Sapi Potong : Optimalisasi Pemanfaatan Tumpi Jagung. Lokakarya Nasional Tanaman Pakan Ternak. Hlm. 183 - 191. Pasuruan: Loka Penelitian Sapi Potong.
[5] Ningrum, F. R. 2010. Pengaruh Penggunaan Kulit Nanas Terhadap Kecernaan Bahan Kering dan Bahan Organik Ransum Kelinci New Zealand White Jantan. Skripsi. Fakultas Pertanian Universitas Sebelas Maret.

[6] Novianty, N. 2014. Kandungan Bahan Pakan Kering Organik Protein Kasar Ransum Berbahan Jerami Padi Daun Gamal Urea Mineral Molase Liquid dengan Perlakuan yang Berbeda. Skripsi. Fakultas Peternakan Universitas Hasanuddin Makasar.

[7] Purbowati, Endang. 2009. Usaha Penggemukan Domba. Cetakan ke 2. Jakarta: Penebar Swadaya.

[8] Purbowati, E., C. I. Sutrisno, E. Beliarti, S. P. S Budhi, W. Lestariana, E. Rianto, dan Kholidin. 2009. Penampilan Produksi Domba Lokal Jantan dengan Pakan Komplit Dari Berbagai Limbah Pertanian dan Agroindustri. Proseding Seminar Nasional Kebangkitan Peternakan. Semarang.

[9] Rianto, E., Haryono dan C.M. Sri Lestari. 2006. Produktivitas Domba Ekor Tipis Jantan yang Diberi Pollard dengan Aras Berbeda. Seminar Nasional Teknologi Peternakan dan Veteriner. Hlm. 431-439.

[10] Siregar, S. B. 1994. Ransum Ternak Ruminansia. Penebar Swadaya. Jakarta.

[11] Wahyono, D.E., dan R. Hardianto. 2004. Pemanfaatan Sumberdaya Pakan Lokal untuk Pengembangan Usaha Sapi Potong. Dalam Lokakarya Nasional Sapi Potong . Hlm. 66 - 77.

[12] Wulandari, S., A. Agus, M. Soejono, M. N. Cahyanto, dan R. Utomo. 2014. Performa Produksi Domba yang Diberi Complete Feed Fermentasi Berbasis Pod Kakao serta Nilai Nutrien Tercernanya secara In Vivo. Buletin Peternakan. Vol. 38(1). Hlm. 43-50.

[13] Zain, M. 2009. Substitusi rumput lapangan dengan kulit buah coklat amoniasi dalam ransum domba lokal. Media Peternakan 32: 47-52 
